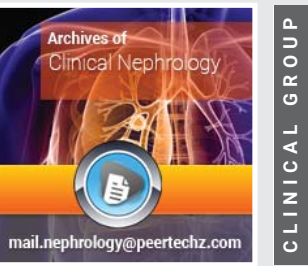

\title{
A new litholytic therapy for nephrolithiasis
}

\section{Papalia T* and Greco R}

Department of Nephrology, Dialysis and Graft Unit, Annunziata Hospital, Cosenza, Italy
Received: 22 February, 2017

Accepted: 01 December, 2020

Published: 02 December, 2020

*Corresponding author: Papalia T, Department of $\mathrm{Ne}$ phrology, Dialysis and Graft Unit, Annunziata Hospital, Cosenza, Italy,

E-mail: teresapapalia@alice.it,teresapapalia@alice.it

Keywords: Phillantus niruri; Urolithiasis; Litholytic drugs; Phytoterapeutical agent

https://www.peertechz.com

\section{Check for updates}

\section{Abstract}

Background and aims: Nephrolithiasis is a widespread disease and it is the most frequent cause of hospitalisation within the urological field. Medical therapy has recently evolved in correcting lithogenous processes and prompting lytic and expulsive processes. Nowadays, among new litholytic drugs, there are phytotherapeutical agents such as the aqueous extract of Phyllantus niruri (Pn). The aim of our study was to evaluate the efficacy of new therapeutic protocols in a youth population affected by Nephrolithiasis.

Methods: We evaluate 40 patients (24 females and 16 males), average age 23 , affected by nephrolithiasis. All of 40 patients were randomized to take either a Phillantus niruri extract $2 \mathrm{gm} /$ daily (n. 20), or placebo (n. 20, control group) for 3 months.

Results: After 3 months of therapy in the treated group the stone free patients were about $65 \%$ while in the control group the stone free patients were about $20 \%$. Moreover we observed that Pn intake reduced urinary calcium in 10 hypercalciuric patients. During the Pn treatment none of the patients has suffered from strong colic pain and there have not been drop-outs.

Conclusions: In our experience the Pn represents an effective alternative to treatment and/or prevention of urolithiasis, although the acting mechanism is not clear. The drug has proven easy to handle, non toxic and cheap.

\section{Introduction}

Urolithiasis is a widespread disease and represents the most frequent cause of hospitalisation within the urological field in western countries $[1,2]$. The prevalence of nephrolithiasis varies between 5 and $10 \%$ and the yearly incidence is about $0,1-$ $6 \%$ in the world population [3].

Over the last 20 years the management of this disease has changed radically. The medical therapy has experienced an evolving role in urolithiasis treatment by correcting lithogenous processes and active expulsion of the stone [4-6].

Nowadays, among new litholytic drugs, there is a phytotherapeutical agent such as the aqueous extract of Phyllantus niruri (Pn) [7].

Pn is a plant belonging to the Euphorbiaceae family, which is so widely distributed, both in many tropical and subtropical countries, and it is generally used in Brazilian folk medicine for the treatment of urolithiasis [8]. Moreover Pn shows antispasmodic and relaxants effects on many contractile tissue.
These effects might also occur in urethral smooth muscle and might contribute to the elimination of smaller calculi [9].

The aim of the study was to evaluate the efficacy of Pn in young patients affected by renal stones of size $<10 \mathrm{~mm}$.

\section{Materials and methods}

From January 2009 to June 2012 we prospectively evalueted 40 outpatients affected by nephrolithiasis. The kidney stones were documented by renal ultrasound scan. Patients of both groups presented caliceal and pelvis stones. None of the patients showed hydronephrosis.

All the 40 patients started a high water intake (about 2000 cc of water/day) and a hyposodic diet (3 gr/day) [10]. Moreover, randomly 20 patients ( 12 females and 8 males, average age $23 \pm 14$ ) were treated with Pn ( 2 gm/day if body weight was less than $50 \mathrm{Kg}$ and $4 \mathrm{gm} /$ day if body weight was over $50 \mathrm{Kg}$ ) and the others 20 patients ( 12 females and 8 males, average age $20 \pm 12$ ) were treated with placebo (control group), for 3 months (Table 1). We applied the student test $t$ to compare 
the two populations. Urinary and blood electrolytes (calcium, phosphorus, potassium, sodium, magnesium, uricaemia), creatinine clearance, urinalysis, urine culture were determined at baseline and at the end of the study. At the beginning of the study the average stone size was $8 \mathrm{~mm}$ (range 4,7 to 11,2 $\mathrm{mm}$ ) in treated group and 7,41 $\mathrm{mm}$ (range 4,5 to $10,1 \mathrm{~mm}$ ) in the control group (p 0,52), Figure 1.

Both groups (treated group and control) underwent ultrasound scan after 3 months. The ultrasound scan was made by the same ultrasound physician, blinded to the treatment arm of the patients.

\section{Results}

We observed, in treated group, n.13 patients (65\%) became stone-free while in the control group only n.4 patients $(20 \%)$ became stone free $(\mathrm{p}<0.001)$. In treated group $\mathrm{n} .10$ patients were hypercalciuric and n. 3 patients had normal calciuria. A stone-free condition was defined as the absence of any stone or residual fragments less than $3 \mathrm{~mm}$. Among examined patients there have not been dropouts. None of the patients suffered by strong colic pain during Pn therapy, while 5 patients within the control group reported colic pain during the 3-months-period.

In the treated group n.10 patients (50\%) were hypercalciuric. After Pn therapy the hypercalciuric patients showed a significant reduction in the mean urinary calcium $(6.2 \pm 0.9$ vs $3.8 \pm 0.9 \mathrm{mg} / \mathrm{Kg} /$ day, $\mathrm{p}<0.005$ ) (Table 2 ). In the control group n. 5 hypercalciuric patients $(25 \%)$ have not presented the same result $(6,0 \pm 1,1$ vs $5,74 \pm 0,8 \mathrm{mg} / \mathrm{Kg} /$ day, $\mathrm{p}$ 0.69). Moreover, in the treated group there were no significant differences in the others mean values of urinary and blood parameters before and after Pn intake (Table 3).

\section{Discussion}

The formation of kidney stones is a relatively complex process [10-12]. Generally, urine contains a certain amount of chemical agents that take part to crystal formation or precipitation. The balance among inhibitors and promoters prevents the formation of kidney stones [10-13]. A crystal forms when molecules able to create a crystal system such as calcium-oxalate, calcium-phosphate, uric acid, and cystine reach a concentration allowing them to aggregate (calculus

Table1: Clinical features.

\begin{tabular}{|c|c|c|}
\hline Characteristics & Treated group & Control group \\
\hline Demographics: & & 20 \\
\hline$N^{\circ}$ patients & 20 & 20 \\
\hline Mean years age & 23 & $12: 8$ \\
\hline Sex (female: male) & $12: 8$ & \\
\hline Stone Characteristics: & & 7,41 mm \\
\hline Average stone size & 8 mm & \\
\hline Therapy: & & n. 0 \\
\hline Pn therapy & all patients & all patients \\
\hline Hyposodic diet & all patients & all patients \\
\hline High fluid intake & & \\
\hline
\end{tabular}

\section{Freq. of distribution}

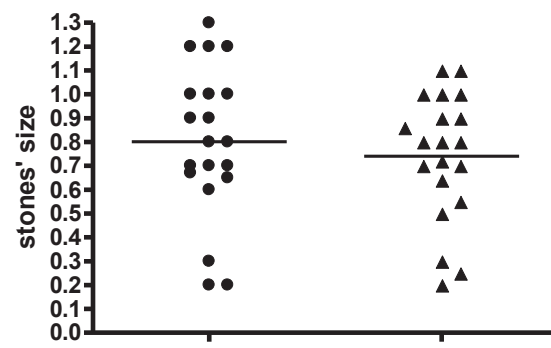

- Treated group

- Control group

Figure 1: Frequence of distribution of stones' size $(\mathrm{mm})$ in both populations.

Table 2: Mean urinary calcium before and after the study in hypercalciuric patients of the two arms.

\begin{tabular}{|c|c|c|c|c|}
\hline Parameters & & Basal & 3 Months & $\mathbf{p}$ \\
\hline (u)Ca mg/Kg/day & Average \pm DS & $6.2 \pm 0.9$ & $3.86 \pm 0.9$ & 0.005 \\
\hline Pn treated patients & Median & 6.2 & 4 & \\
\hline $\begin{array}{c}\text { (u) Ca mg/Kg/day } \\
\text { Pn free patients }\end{array}$ & Average \pm DS & $6,0 \pm 1,1$ & $5,74 \pm 0,8$ & 0.69 \\
\hline
\end{tabular}

Table 3: Mean urinary and blood parameters before and after the study in the treated group.

\begin{tabular}{|c|c|c|c|c|}
\hline Parameters & & Basal & 3 Months & $\mathbf{p}$ \\
\hline $\mathrm{Na}, \mathrm{mEq} / \mathrm{L}$ & Average $\pm \mathrm{DS}$ & $141,4 \pm 3,2$ & $141 \pm 2,8$ & $\mathrm{~ns}$ \\
\hline $\mathrm{Ca}, \mathrm{mg} / \mathrm{dl}$ & & $9,06 \pm 0,32$ & $8,9 \pm 0,41$ & $\mathrm{~ns}$ \\
\hline $\mathrm{K}, \mathrm{mEq} / \mathrm{L}$ & & $4,25 \pm 0,41$ & $4,12 \pm 0,5$ & $\mathrm{~ns}$ \\
\hline $\mathrm{P}, \mathrm{mg} / \mathrm{dl}$ & & $3,56 \pm 0,33$ & $3,66 \pm 0,30$ & $\mathrm{~ns}$ \\
\hline Uric acid, mg/dl & & $3,78 \pm 0,78$ & $3,83 \pm 0,65$ & $\mathrm{~ns}$ \\
\hline (u)Na, mmol/day & & $115,8 \pm 36,6$ & $106 \pm 29,8$ & $\mathrm{~ns}$ \\
\hline (u) P, mg/day & & $401 \pm 228$ & $397 \pm 215$ & $\mathrm{~ns}$ \\
\hline (u)K, mmol/day & & $40,0 \pm 12,8$ & $38,7 \pm 11,5$ & $\mathrm{~ns}$ \\
\hline (u)Uric acid, mg/day & & $408,7 \pm 97,5$ & $398,2 \pm 95,4$ & $\mathrm{~ns}$ \\
\hline
\end{tabular}

nucleation) [10-15]. Moreover urine contains agents such as glycosaminoglycans, uroporfirine, nephrocalcine, magnesium and citrates that are able to inhibit over-saturation and crystallisation $[16,17]$. Therefore, the over-saturation of solutes, the reduced excretion of citrates, the decrease in urinary volume, $\mathrm{pH}$ changes and urinary anomalies all are potential factors in lithogenesis. Litholytic therapy represents an highly effective treatment for the urolithiasis' promoting factors $[3,18]$. New therapeutic aids include the use of phytotherapy agents such as Pn $[7,19]$.

In our study we report the results of a Pn therapy in 20 patients suffering from nephrolithiasis. Compared to the control group, these patients have shown a higher complete lithiasis clearance (stone-free) percentage.

Several authors have investigated the Pn mechanism of action. Some authors described the Pn powerful inhibitory effect on CaOX crystal adhesion and suggested that Pn intake may reduce urinary calcium in patients with hypercalciuria $[19,20]$. On the other hands, Freitas et al suggested that this effect was related to a higher incorporation of glycosaminoglycans into the stone, independently from urinary excretion of citrate and magnesium. In fact the calculi from Pn treated group 
had a higher content of GAGs, suggesting that Pn reduces the deposition of crystalline particles $[10,20]$.

Moreover our findings have also highlighted a significant reduction in the concentration of urinary calcium in 10 patients with hypercalciuria after Pn therapy. Indeed, previous studies have assessed that Pn significantly reduces calcium urinary excretion in stone-forming patients, maybe through the significant reduction in $\mathrm{CaOx}$ endocytosis consequent to increase in cytosolic calcium intra or extracellular sources [1922]. Thus Pn might prevent the internalization of CaOx crystals by changes in calcium metabolism. Instead, no control arm patient showed improvement in hypercalciuria.

Although the evidence is encouraging, the mechanism action of Pn is not totally understood. According to our experience, the drug can be a non-toxic, low-cost and effective alternative to treatment and/or prevention of urolithiasis.

Further studies are likely to provide additional confirmation of Pn efficacy in medical therapy for stone disease.

\section{References}

1. Hollingsworth JM, Rogers MAM, Kaufman SR, Bradford TJ, Saint S, et al (2006) Medical therapy to facilate urinary stone passage: a meta-analysis. Lancet 368: 1171-1179. Link: https://bit.ly/37mbWVE

2. Stamatelou KK, Francis ME, Jones CA, Nyberg LM, Curhan GC (2003) Time trends in reported prevalence of kidney stones in the United States. Kidney Int 63:1817-1823. Link: https://bit.ly/37rKhT2

3. Tiselius HG (2003) Epidemiology and medical management of stone disease BJU Int 91: 758. Link: https://bit.ly/2JfGCjr

4. Evan AP, Coe FL, Lingeman JE, Worcester E (2005) Insights on the pathology of kidney stone formation. Urol Res 33: 383-389. Link: https://bit.ly/33rZ6E7

5. Taylor EN, Curhan GC (2006) Diet and fluid prescription in stone disease Kidney Int 70: 835-839. Link: https://bit.ly/39uiYu1

6. Pattaras JG, Moore RG (1999) Citrate in the management of urolithiasis. J Endourol 9: 687-692. Link: https://bit.ly/33wlaxk

7. Barros ME, Schor N, Boim MA (2003) Effects of an aqueous extract from Phyllanthus niruri on calcium oxalate crystallization in vitro. Urol Res 30: 374 379. Link: https://bit.ly/3fTcjKW

8. Calixto JB, Santos ARS, Filho VC, Yunes RA (1998) A review of the Plants of Genus Phyllanthus: their Chemistry, Pharmacology and Therapeutic potential. Med Res Rev 18: 225-258. Link: https://bit.ly/36pdr64

9. Freitas AM, Schor N, Boim MA (2002) The effect of Phyllanthus niruri on urinary inhibitors of calcium oxalate crystallization and other factors associated with renal stone formation. BJU International 89: 829-834. Link: https://bit.ly/3fRyllG

10. Pak CY, Odvina CV, Pearles MS, Sakhae EK, Peterson RD, et al. (2005) Effect of dietary modification on urinary stone risk factors. Kidney Int 65: 2264-2273. Link: https://bit.ly/39uirbu

11. Lieske JC, Leonard R, Swift H, Toback FG (1996) Adhesion of calcium oxalate monohydrate crystal to anionic sites on the surface of renal epithelial cells. Am J Physiol 270: F192-F199. Link: https://bit.ly/2Vnq6jK
12. VanDervoort K, Wiesen J, Frank R, Veneto S, Crosby V, et al. (2007) Urolithiasis in pediatric patients: a single center study of incidence, clinical presentation and outcome. J Urol 177: 2300-2305. Link: https://bit.ly/36n6lys

13. Lieske J, Hammes MS, Toback G (1996) Role of calcium oxalate monohydrate crystal interactions with renal epithelial cells in the pathogenesis of nephrolithiasis: a review. Scanning Microsc 10: 519-534. Link: https://bit.ly/3InFUOb

14. Shekarriz B, Stoller ML (2002) Uric acid nephrolithiasis: Current concepts and controversies. J Urol 168: 1307-1314. Link: https://bit.ly/2Vo2viR

15. Borghi L, Meschi T, Amato F, Brigati A, Novarini A, et al. (1996) Urinary volume, water and recurrences idiopathic calcium nephrolithiasis: A 5-year randomized prospective study. J Urol 155: 839-843. Link: https://bit.ly/3qonMHB

16. Verkoelen CF, Verhulst A (2007) Proposed mechanism in renal tubular crystal retention. Kidney Int 72: 13-18. Link: https://bit.ly/2KWKupV

17. Roberts SD, Resnick MI (1986) Glycosaminoglycans content of stone matrix. J Urol 135: 1078-1083. Link: https://bit.ly/36tVxiN

18. Moe OW (2006) Kidney stones: Pathophysiology and medical management Lancet 367: 333. Link: https://bit.ly/36pBJNp

19. Parmar MS (2004) Kidney stones. BMJ 328: 1420. Link: https://bit.ly/3fU4jtt

20. Campos AH, Schor N (1999) Phyllanthus niruri Inhibits Calcium Oxalate Endocytosis by Renal Tubular cells: its role in Urolithiasis. Nephron 81: 393 397. Link: https://bit.ly/39voNHK

21. Micali S, Sighirolfi MC, De Carne C, De Stefani S, Bianchi G, et al. (2006) Medical therapy of urolithiasis. Review. J Endourology 20.

22. Nishiura JL, Campos AH, Boim MA, Heilberg IP, Shor N (2004) Phyllantus niruri normalizes elevated urinary calcium levels in calcium stones forming (CSF) patients. Urol Res 32: 362-366. Link: https://bit.ly/3ljCgEM

Discover a bigger Impact and Visibility of your article publication with

Peertechz Publications

\section{Highlights}

- Signatory publisher of ORCID

- Signatory Publisher of DORA (San Francisco Declaration on Research Assessment)

- Articles archived in worlds' renowned service providers such as Portico, CNKI, AGRIS, TDNet, Base (Bielefeld University Library), CrossRef, Scilit, J-Gate etc.

* Journals indexed in ICMJE, SHERPA/ROMEO, Google Scholar etc.

* OAI-PMH (Open Archives Initiative Protocol for Metadata Harvesting)

* Dedicated Editorial Board for every journal

* Accurate and rapid peer-review process

* Increased citations of published articles through promotions

* Reduced timeline for article publication

Submit your articles and experience a new surge in publication services (https://www.peertechz.com/submission).

Copyright: @ 2020 Papalia T, et al. This is an open-access article distributed under the terms of the Creative Commons Attribution License, which permits unrestricted use distribution, and reproduction in any medium, provided the original author and source are credited. 